\title{
Attenuation of UV-B exposure-induced inflammation by abalone hypobranchial gland and gill extracts
}

\author{
CHITRAPORN KUANPRADIT ${ }^{1}$, YAMARATEE JAISIN ${ }^{1}$, SUMON JUNGUDOMJAROEN $^{1}$, SHAHIDA AKTER MITU ${ }^{2}$, \\ SRISOMBAT PUTTIKAMONKUL ${ }^{1}$, PRASERT SOBHON ${ }^{3,4}$ and SCOTT F. CUMMINS ${ }^{2}$ \\ ${ }^{1}$ Faculty of Medicine, Srinakharinwirot University, Bangkok 10110, Thailand; \\ ${ }^{2}$ Genecology Research Center, Faculty of Science, Health and Education, University of the Sunshine Coast, \\ Maroochydore, DC, QLD 4558, Australia; ${ }^{3}$ Faculty of Science, Mahidol University, Bangkok 10400; \\ ${ }^{4}$ Faculty of Allied Health Sciences, Burapha University, Chon Buri 20131, Thailand
}

Received October 23, 2016; Accepted February 2, 2017

DOI: $10.3892 / \mathrm{ijmm} .2017 .2939$

\begin{abstract}
Exposure to solar ultraviolet B (UV-B) is a known causative factor for many skin complications such as wrinkles, black spots, shedding and inflammation. Within the wavelengths 280-320 nm, UV-B can penetrate to the epidermal level. This investigation aimed to test whether extracts from the tropical abalone [Haliotis asinina (H. asinina)] mucus-secreting tissues, the hypobranchial gland (HBG) and gills, were able to attenuate the inflammatory process, using the human keratinocyte HaCaT cell line. Cytotoxicity of abalone tissue extracts was determined using an AlamarBlue viability assay. Results showed that $\mathrm{HaCaT}$ cells could survive when incubated in crude $\mathrm{HBG}$ and gill extracts at concentrations between $<11.8$ and $<16.9 \mu \mathrm{g} / \mathrm{ml}$, respectively. Subsequently, cell viability was compared between cultured $\mathrm{HaCaT}$ cells exposed to serial doses of UV-B from 1 to $11(\mathrm{x} 10) \mathrm{mJ} / \mathrm{cm}^{2}$ and containing 4 different concentrations of abalone extract from both the $\mathrm{HBG}$ and gill $(0,0.1,2.5,5 \mu \mathrm{g} / \mathrm{ml})$. A significant increase in cell viability was observed $(\mathrm{P}<0.001)$ following treatment with 2.5 and $5 \mu \mathrm{g} / \mathrm{ml}$ extract. Without extract, cell viability was significantly reduced upon exposure to UV-B at 4 $\mathrm{mJ} / \mathrm{cm}^{2}$. Three morphological changes were observed in $\mathrm{HaCaT}$ cells following UV-B exposure, including i) condensation of cytoplasm; ii) shrunken cells and plasma membrane bubbling; and iii) condensation of chromatin material. A calcein AM-propidium iodide live-dead assay showed that cells could survive cytoplasmic condensation, yet cell death occurred when damage also included membrane bubbling and chromatin changes. Western blot analysis of HaCaT cell COX-2, p38, phospho-p38, SPK/JNK and phospho-SPK/JNK following exposure to $>2.5 \mu \mathrm{g} / \mathrm{ml}$ extract showed a significant decrease
\end{abstract}

Correspondence to: Dr Scott F. Cummins, Genecology Research Center, Faculty of Science, Health and Education, University of the Sunshine Coast, 90 Sippy Downs Drive, Maroochydore, DC, QLD 4558, Australia

E-mail: scummins@usc.edu.au

Key words: abalone, gland, ultraviolet, inflammation in intensity for COX-2, phospho-p38 and phospho-SPK/JNK. The present study demonstrated that abalone extracts from the HGB and gill can attenuate inflammatory proteins triggered by UV-B. Hence, the contents of abalone extract, including cellmetabolites and peptides, may provide new agents for skin anti-inflammation, preventing damage due to UV-B.

\section{Introduction}

Ultraviolet (UV) radiation is a major source of skin damage, where daylight UV is composed of three different types classified by wavelengths: UV-A (320-400 nm), UV-B (290-320 nm) and UV-C (<290 nm) (1-5). Skin inflammation after UV exposure is caused by UV-B since it easily triggers the cross-linking of macromolecules, ring-structures and repeated linear molecules $(2,3,5)$.

UV-induced damage can be measured at the cellular level through the production of reactive oxygen species (ROS), leading to genetic mutations, the suppression of gene expression, and inhibition of peptide repair, resulting in inflammation and possibly leading to skin cancer $(2,3,5-9)$. There are three major pathways of UV-induced skin inflammation. The first pathway involves the COX-2 mechanism whereby UV-B exposure induces arachidonic acid release from the phospholipid membrane and the COX-2 enzyme converts it to prostaglandins and free radical molecules (10-13). It has been reported that COX-2 and prostaglandin E2 elevations may be responsible for inflammation and tumorigenesis $(11,13,14)$. The second includes the mitogen-activated protein kinase (MAPK) signaling pathways. After exposure to UV-B, phosphorylation of threonine and tyrosine leads to the activation of the MAPK protein kinase family. SPK/JNK and p38 kinase are activated (phospho-SPK/JNK and phospho-p38) in response to cellular stress and play a protective and pro-apoptotic role $(5,15)$. Thus, $\mathrm{UV}-\mathrm{B}$ is the main cause of inflammation in human keratinocytes via the MAPK pathways, JNK and p38 (16). The third includes the epidermal growth factor receptor (EGFR) pathway where UV-B-phosphorylated EGFR induces inflammation and skin tumorigenesis. Previous studies have demonstrated that EGFR regulates activation of $\mathrm{p} 38$ kinase leading to increased COX-2 and cytokine expressions $(17,18)$. 
The beneficial properties of mucus in UV protection have been established from research on fish. For example, coral reef fish can withstand UV due to mycosporine-like amino acids (MAAs) found in the external epithelial mucus that absorb UV (19). Relatively little is known regarding how mollusc mucus-derived compounds may mitigate UV-induced damage; yet, there is ample knowledge that molluscs, including abalone, snails, slugs, can survive in UV-exposed ecological niches. Molluscan mucus has increasingly been found to contain properties which are being exploited for use in medicines and cosmetics (20-23). For example, mucus-derived mucin compounds mixed with a honey gel were found to promote wound healing (24). Moreover, land snail (Achatina fulica) mucin promotes wound healing and provides anti-bacterial protection from Staphylococus aureus and Staphylococus epidermidis (25). Snail mucus has also been utilized as a skin cosmetic to promote skin regeneration, and as a treatment for acne, pigmentation, scarring, wrinkles, and inflammation and sun protection (23,26-29).

The abalone is a gastropod marine mollusc commonly recognized as a food source due to an edible foot muscle and constitutes an important culture industry for many countries $(30,31)$. On the other hand, its visceral organs have not been recognized as valuable. Although the visceral organs do not appear to contain separate highly developed mucous glands as observed in snails, they do secrete copious amounts of mucus via numerous organs, including the foot muscle, hypobranchial gland (HBG) and gills $(32,33)$. This mucus appears to be an important source for chemosensory cues required for nonspecific aggregation and larval settlement (34-37), and likely contains protective properties.

Human keratinocyte HaCaT cells have often been used for in vitro assays to understand epidermal homeostasis and processes associated with disease or injury. For example, $\mathrm{HaCaT}$ cells can be used to study molecular mechanisms related to abnormal human $\beta 2$-defensin in response to cell cytokines (38). They have also been used to assess anti-inflammation and apoptosis from extracts derived from natural products, such as pearls (39) or pure compounds such as tectroside (40). In the present study, we explored the cell protective effects of abalone [Haliotis asinina $(H$. asinina)] extracts derived from the HBG and gills on $\mathrm{HaCaT}$ cells following UV-B exposure. For the majority of abalone species, the shell covers the entire animal, however in $H$. asinina the shell is reduced, leaving a significant proportion of the animal's body exposed. Its tropical distribution means that it is exposed to varying levels of UV. We demonstrated that there is significant improvement in cell survival following $H$. asinina tissue extract application. This is supported by our analysis of changes in the expression of inflammation-related proteins.

\section{Materials and methods}

Abalone HBG and gill extraction. Twenty adult male and female $H$. asinina (1-1.5 years of age) were obtained from the Coastal Aquaculture Research and Development Centre, Department of Fisheries, Prachuabkirikhan Province, Thailand. Animals were anesthetized by immersion in an ice bath for $15 \mathrm{~min}$. The HBG and gills were rapidly dissected, washed and frozen in liquid nitrogen for storage at $-80^{\circ} \mathrm{C}$. Proteins and metabolites were extracted by homogenizing at $4^{\circ} \mathrm{C}$ in $0.1 \%$ trifluoroacetic acid using a Polytron homogenizer (Brinkmann Instruments, Westbury, NY, USA), followed by sonication. The extracts were centrifuged $\left(15,000 \mathrm{x} \mathrm{g}\right.$ for $30 \mathrm{~min}$ at $\left.4^{\circ} \mathrm{C}\right)$ and then the supernatant was lyophilized.

Human keratinocyte culture. HaCaT cells were purchased from Cell Lines Service (CLS, Eppelheim, Germany). Cells were cultured under standard conditions of $5 \% \mathrm{CO}_{2}$ in air at $37^{\circ} \mathrm{C}$ with medium renewal every 2 days. Culturing medium was Dulbecco's modified Eagle's medium (DMEM) (Gibco BRL, Gaithersburg, MD, USA) containing $5 \%$ fetal bovine serum (FBS), $10 \mu \mathrm{g} / \mathrm{ml}$ of penicillin/streptomycin. Cultured $\mathrm{HaCaT}$ cells were plated at a density of $5 \times 10^{5} \mathrm{cells} / \mathrm{cm}^{2}$ onto $60 \times 100 \mathrm{~cm}^{2}$ tissue culture-treated Petri dishes (SPL Life Sciences Co., Ltd., Pochoen, Korea).

Cytotoxicity test of abalone $H B G$ and gills extracts. $\mathrm{HaCaT}$ cells were trypsinized from subconfluent cultures by adding Trypsin-EDTA (0.25\%) solution (Gibco BRL), and incubated for $10 \mathrm{~min}$ with regular gentle shaking. The trypsin reaction was stopped by adding $10 \mathrm{ml}$ of DMEM (Gibco BRL) containing 10\% FBS. The cell suspension was then centrifuged at $1,000 \mathrm{x} \mathrm{g}$ for $5 \mathrm{~min}$ at $25^{\circ} \mathrm{C}$. The cell pellet was re-suspended in $2 \mathrm{ml}$ of culturing medium with 5\% FBS and mixed by vortexing. The cells were counted with a hemocytometer. Then, $1 \times 10^{5}$ cells were equally seeded into each well of a 96 -well black plate and incubated at $37^{\circ} \mathrm{C}$ for $24 \mathrm{~h}$. After that, the culturing medium was removed and replaced with $200 \mu 1$ of serial abalone extracts in $1 \%$ serum-media. Serial concentrations of abalone extracts were from 0.1 to $50 \mathrm{mg} / \mathrm{ml}$. The cells were then incubated at $37^{\circ} \mathrm{C}$ for $24 \mathrm{~h}$ and $100 \mu \mathrm{l}$ of a $10 \%$ AlamarBlue solution (Invitrogen, Carlsbad, CA, USA) in serum-free medium was directly added to each well. The plate was incubated at $37^{\circ} \mathrm{C}$ for $4 \mathrm{~h}$ and the absorbance was measured at 540 and $630 \mathrm{~nm}$ with a fluorescent spectrophotometer (Epoch; BioTek, Winooski, VT, USA). The percentage of cell viability was analyzed by GraphPad Prism version 6 (GraphPad Software, Inc., San Diego, CA, USA) using one-way ANOVA at $\mathrm{P}<0.001$.

UV-B irradiation of HaCaT cells. BLX-312 ultraviolet radiometer UV-B incubator emitted UV-B light with a wavelength of 300-320 nm. Irradiance was measured by UV sensor. To test UV-B irradiation, cultured $\mathrm{HaCaT}$ cells were divided into 4 groups: a control group and 3 experimental groups. In the control group, cells were exposed to serial dosages of UV-B from 10 to $110 \mathrm{~mJ} / \mathrm{cm}^{2}$. In the experimental groups, cells are incubated with 10,100 and $200 \mu \mathrm{g} / \mathrm{ml}$ abalone extract prior to and during the serial UV-B exposure. Then, cell viability, morphological changes and inflammatory cytokine expression levels were observed and measured by AlamarBlue, calcein AM-propidium iodide (PI) live-dead staining and western blot analysis.

AlamarBlue cell viability assay to compare the UV-B resistance of the control group with abalone extract groups. $\mathrm{HaCaT}$ cells were trypsinized from subconfluent cultures by adding trypsin solution, incubated for $10 \mathrm{~min}$ with regular gentle shaking. The trypsin reaction was stopped by adding $10 \mathrm{ml}$ of DMEM 
culture medium containing $10 \%$ FBS. The cell suspension was then centrifuged at $1,000 \mathrm{x}$ g for $5 \mathrm{~min}$ at $25^{\circ} \mathrm{C}$. The cell pellet was re-suspended in $2 \mathrm{ml}$ of culturing-medium with $5 \%$ FBS and properly mixed by vortexing. The cells were counted with a hemocytometer. Then, $1 \times 10^{5}$ cells were equally seeded into each well of a 96 -well black-plate and incubated at $37^{\circ} \mathrm{C}$ for $24 \mathrm{~h}$. After that, the culture medium was removed and replaced with $100 \mu \mathrm{l}$ of serum-free medium. Ready to test cell plate was covered by a black sticker except one column opened for UV-B exposure. UV-B was emitted at $10 \mathrm{~mJ} / \mathrm{cm}^{2}$, and then the UV-B exposure was stopped for $5 \mathrm{~min}$ and the next column sticker was removed and the next $10 \mathrm{~mJ} / \mathrm{cm}^{2} \mathrm{UV}-\mathrm{B}$ dose was administered. The same protocol was repeating and continuing 10 times. Thus, the first column was exposed to $110 \mathrm{~mJ} / \mathrm{cm}^{2}$ of UV-B, the 11th column received $1 \mathrm{~mJ} / \mathrm{cm}^{2}$ and the last column was covered and exposed to no UV. Then, $100 \mu \mathrm{l}$ of $10 \%$ AlamarBlue solution in serum-free medium was added to each well. The plate was incubated in $37^{\circ} \mathrm{C}$ for $4 \mathrm{~h}$ and the absorbance was measured at 540 and $630 \mathrm{~nm}$ with a fluorescent spectrophotometer (Epoch; BioTek). The number of viable cell was calculated as described previously (41). Next, viability of the cells in the experimental groups was tested in the same way as the control group but either the abalone HBG or gill extract was administered. In the experimental groups, the cells were incubated with abalone peptides at the concentrations of $10,100,200 \mu \mathrm{g} / \mathrm{ml}$ for $8 \mathrm{~h}$ prior to and during the UV-B exposure. After that the serial UV-B exposure and viability test was carried out in the same way as the control group. The percentage of cell viability was analyzed by GraphPad Prism version 6 (GraphPad Software, Inc.) using one-way ANOVA at $\mathrm{P}<0.001$.

Calcein AM-PI live-dead assay and morphological change. Live-dead solution was prepared by adding: i) $250 \mu \mathrm{l}$ of calcein AM (1 mg/ml stock solution); ii) $100 \mu \mathrm{l} \mathrm{PI} \mathrm{(1} \mathrm{mg/ml}$ stock solution; iii) $3 \mathrm{ml}$ of $5 \mathrm{X}$ binding buffer into serum-free medium to make $15 \mathrm{ml}$ of calcein AM-PI live-dead staining solution (Molecular Probes Life Technologies, Carlsbad, CA, USA). The ready-to-use solution was maintained at $4^{\circ} \mathrm{C}$. The fully grown $\mathrm{HaCaT}$ cells in 24-well Petri dishes were divided into two groups: i) control group; and ii) experimental group. In the control group, each dish was exposed to the serial UV-B doses started from $0,10,20,30,40,50,60,70,80,90,100$, $110 \mathrm{~mJ} / \mathrm{cm}^{2}$. After every $10 \mathrm{~mJ} / \mathrm{cm}^{2}$, the culture dish was taken out of an incubator and incubated at room temperature for $5 \mathrm{~min}$ and then put back in and given the next dose of $10 \mathrm{~mJ}$ of UV-B. In the experimental group, $100 \mu \mathrm{g}$ of abalone HBG and gill extracts (1:1) was incubated with the cultured cells for $8 \mathrm{~h}$ prior and during UV-B exposure. Images were captured using phase contrast and fluorescence modes, with an inverted digital microscope (EVOS FLC, Life Technologies, Grand Island, NY, USA).

Protein determination and western blot analysis. Fully grown $\mathrm{HaCaT}$ cells in Petri dishes were divided into three groups: i) control group in which cells were cultured normally; ii) UV-B group in which cells were exposed to UV-B at $3 \times 10$ and $5 \times 10 \mathrm{~mJ} / \mathrm{cm}^{2}$; and iii) abalone peptide-treated group in which cells were incubated with $100 \mu \mathrm{g} / \mathrm{ml}$ peptides prior and during UV-B exposure and the cells were exposed to UV-B at $3 \times 10$ and $5 \times 10 \mathrm{~mJ} / \mathrm{cm}^{2}$. After that, confluent cells were scraped and sonicated in $5 \mathrm{X}$ lysis buffer containing Protease Inhibitor Cocktail (Merck Millipore, Darmstadt, Germany). Then, the lysates were centrifuged at $15,000 \times \mathrm{g}$ at $4^{\circ} \mathrm{C}$ for $30 \mathrm{~min}$ and the supernatants were frozen in liquid nitrogen. The frozen protein samples were lyophilized in a freeze dryer (Scanvac CoolSafe 110-4 PRO). Approximately $25 \mu \mathrm{g}$ of extract was re-suspended in $0.1 \mathrm{M}$ phosphate-buffered saline (PBS) and mixed with loading dye containing $50 \mathrm{mM}$ Tris- $\mathrm{HCl}, 10 \%$ glycerol, 2\% SDS, $100 \mathrm{mM}$ DTT and $0.1 \%$ bromophenol blue. Samples were separated using $15 \%$ sodium dodecyl sulfate polyacrylamide gel electrophoresis (SDS-PAGE) . Proteins were then transferred to $0.45-\mu \mathrm{m}$ polyvinylidene fluoride membrane. The membranes were blocked for $1 \mathrm{~h}$ by blocking solution contained $4 \%$ non-fat dry milk, $2 \%$ bovine serum albumin (BSA) and $0.1 \%$ Tween-20 in Tris-buffered saline (TBS) $\mathrm{pH}$ 7.6. Polyclonal antibodies for COX-2 (ab52237), SPK/JNK (ab112501), phosphoSPK/JNK (ab4821), p38 (ab31828) and phospho-p38 (ab4822) were purchased from Abcam (Cambridge, UK) and were used at a 1:1,000 dilution to detect expression levels of the above proteins. The membranes were washed and incubated for $45 \mathrm{~min}$ with the secondary antibody (anti-rabbit HRP conjugated; Amersham plc, Amersham, UK) at a 1:5,000 dilution. Then, the protein bands were visualized by enhanced chemiluminescence (Amersham plc) under GENE GNOME (Syngene Bioimaging Private Ltd., Gurgaon, India). The western blot analyses were repeated in triplicate and band density was quantified using densitometry UN-SCAN-IT software (Silk Scientific, Inc., Orem, UT, USA). Protein expression levels were analyzed by GraphPad Prism version 6 (GraphPad Software, Inc.) using Dunnett's multiple comparison test.

\section{Results}

Cytotoxicity of extracts from abalone $H B G$ and gills. Optimal doses of abalone HBG and gill extracts were determined using an AlamarBlue cytotoxicity assay (Fig. 1A and B). For extracts derived from $\mathrm{HBG}$, the maximal concentration that enabled cell survival of $>50 \%$ was at $12.5 \mu \mathrm{g} / \mathrm{ml}$ (Fig. 1A and C). For extracts derived from gills, the concentration was at $12.5 \mu \mathrm{g} / \mathrm{ml}$ (Fig. 1B and D). Based on these results, subsequent experiments were performed using concentrations of $0.5,2.5,5.0 \mu \mathrm{g} / \mathrm{ml}$ of abalone tissue extracts.

Comparison of cell viability between $U V$-B control group and extract-treated groups. HaCaT cells were exposed to serial doses of UV-B, starting from $1 \times 10$ to $11 \times 10 \mathrm{~mJ} / \mathrm{cm}^{2}$, and then cell viability was compared between the four groups treated with the HBG and gill extracts $(0,0.1,2.5$ and $5.0 \mu \mathrm{g} / \mathrm{ml}$ with UV-B). At $1 \times 10$ to $3 \times 10 \mathrm{~mJ} / \mathrm{cm}^{2}$ UV-B, there was no difference in cell viability among the four groups. At $4 \times 10 \mathrm{~mJ} / \mathrm{cm}^{2} \mathrm{UV}-\mathrm{B}$, the extract groups showed a significant increase in cell viability compared to the control group (Fig. 2A). In the control group, the cell viability was $<50 \%$ at $6 \times 10 \mathrm{~mJ} / \mathrm{cm}^{2} \mathrm{UV}-\mathrm{B}$, while in the extract groups it remained at $>80 \%$. Moreover, HaCaT cell survival was at $>50 \%$ following $9 \times 10 \mathrm{~mJ} / \mathrm{cm}^{2} \mathrm{UV}-\mathrm{B}$. HaCaT cell survival rates were further analyzed using a calcein AM-PI live-dead staining assay (Fig. 2B-I). In the 0 and $0.5 \mu \mathrm{g} / \mathrm{ml}$ extract-treated groups, $5 \times 10 \mathrm{~mJ} / \mathrm{cm}^{2} \mathrm{UV}-\mathrm{B}$ resulted in almost $50 \%$ cell death (Fig. $2 \mathrm{~B}$ and $\mathrm{C}$ ), while the survival rate was 
A

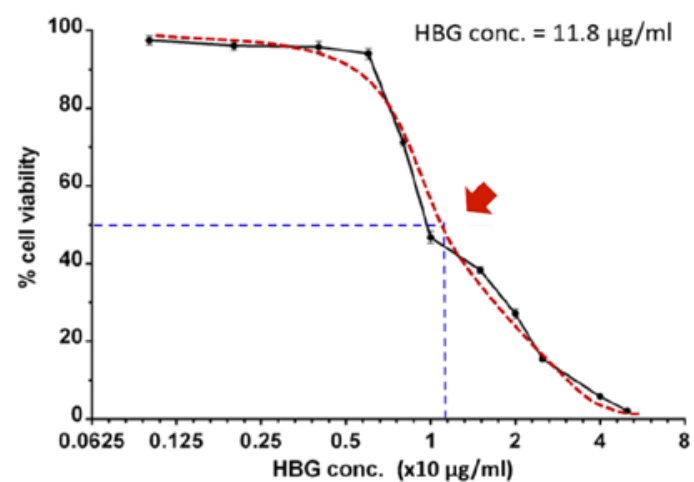

B Gill cytotoxicity

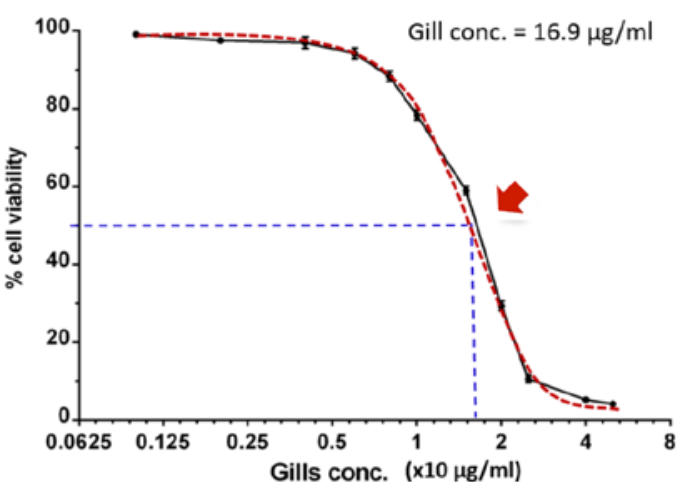

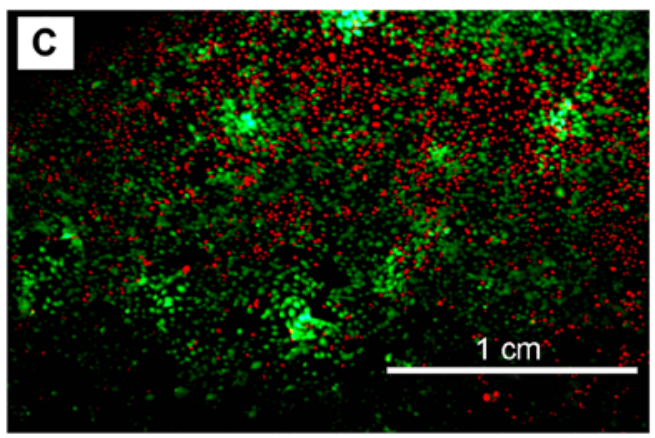

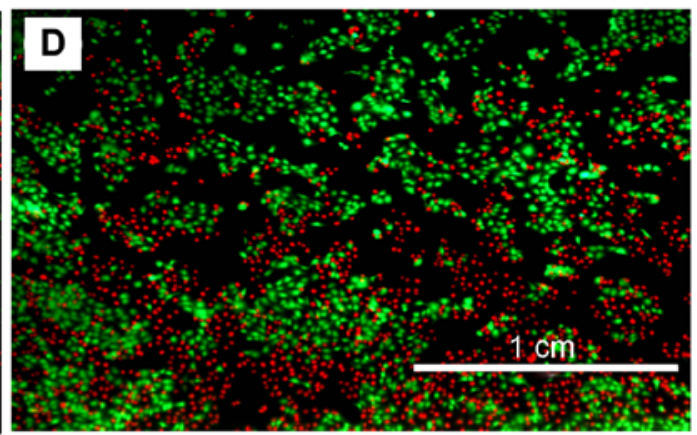

Figure 1. Analysis of the effective dose of abalone HBG and gill extracts on cell viability. Cytotoxicity test from abalone (A) HBG extract and (B) gill extract, using an AlamarBlue cell viability assay. Red arrows show the maximal concentrations of extract which allows for cell survival of $>50 \%$. (C and D) Live-dead staining (calcein AM-PI) of HaCaT cells treated with $12.5 \mu \mathrm{g} / \mathrm{ml} \mathrm{HBG}$ and gill extract, respectively. HBG, hypobranchial gland; PI, propidium iodide.
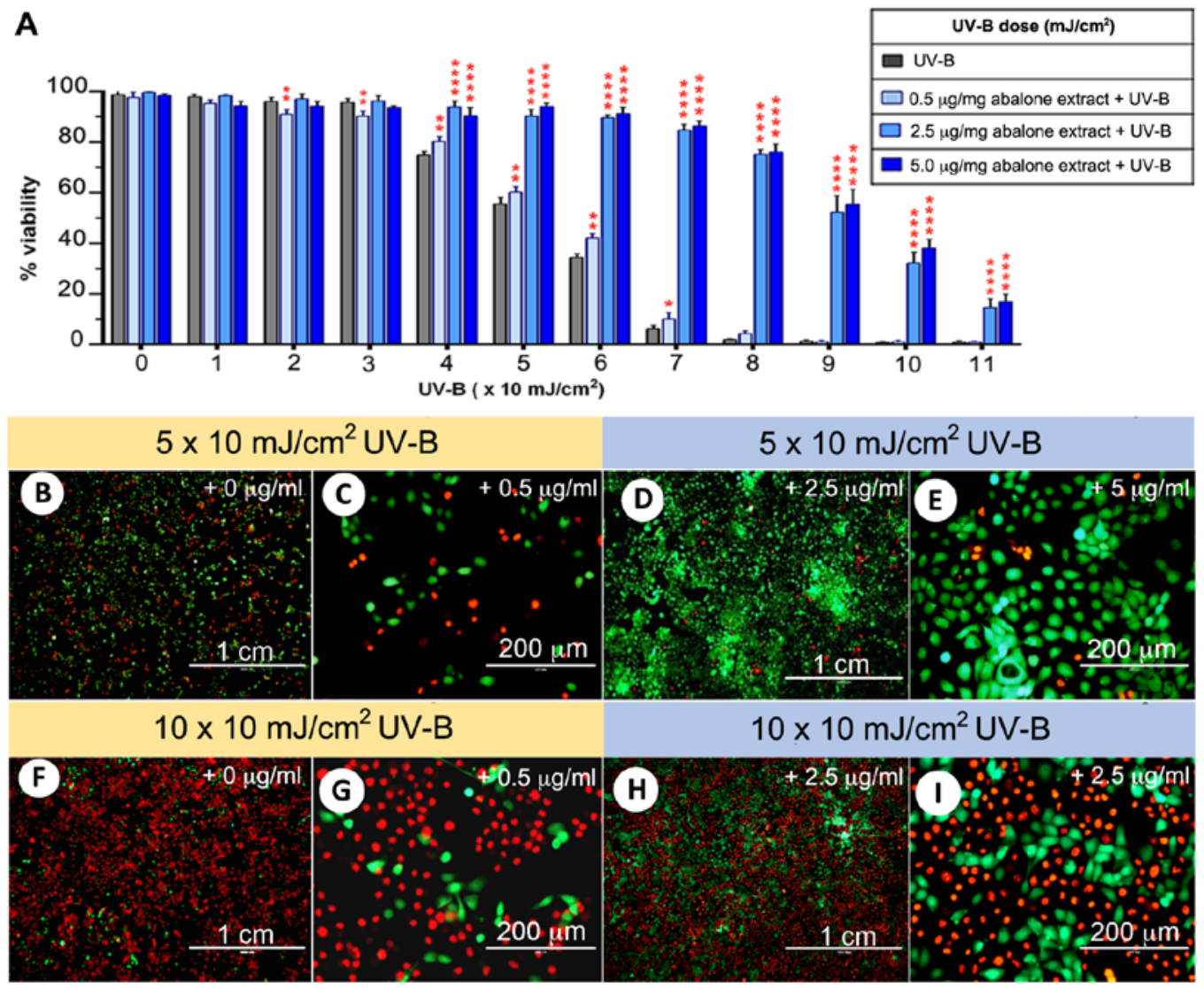

Figure 2. Analysis of effective doses for abalone HBG and gill extract under UVB and HaCaT cell viability. (A) Graph comparing HaCaT cell viability among the four groups. Significant difference in cell viability when compared to the control group is shown at ${ }^{* * * *} \mathrm{P}<0.001,{ }^{* *} \mathrm{P}<0.01$ and ${ }^{*} \mathrm{P}<0.05$. (B-I) Representative images of HaCaT cells treated with UV-B with and without extract, showing live-dead staining as indicated by green and red, respectively. HBG, hypobranchial gland. 

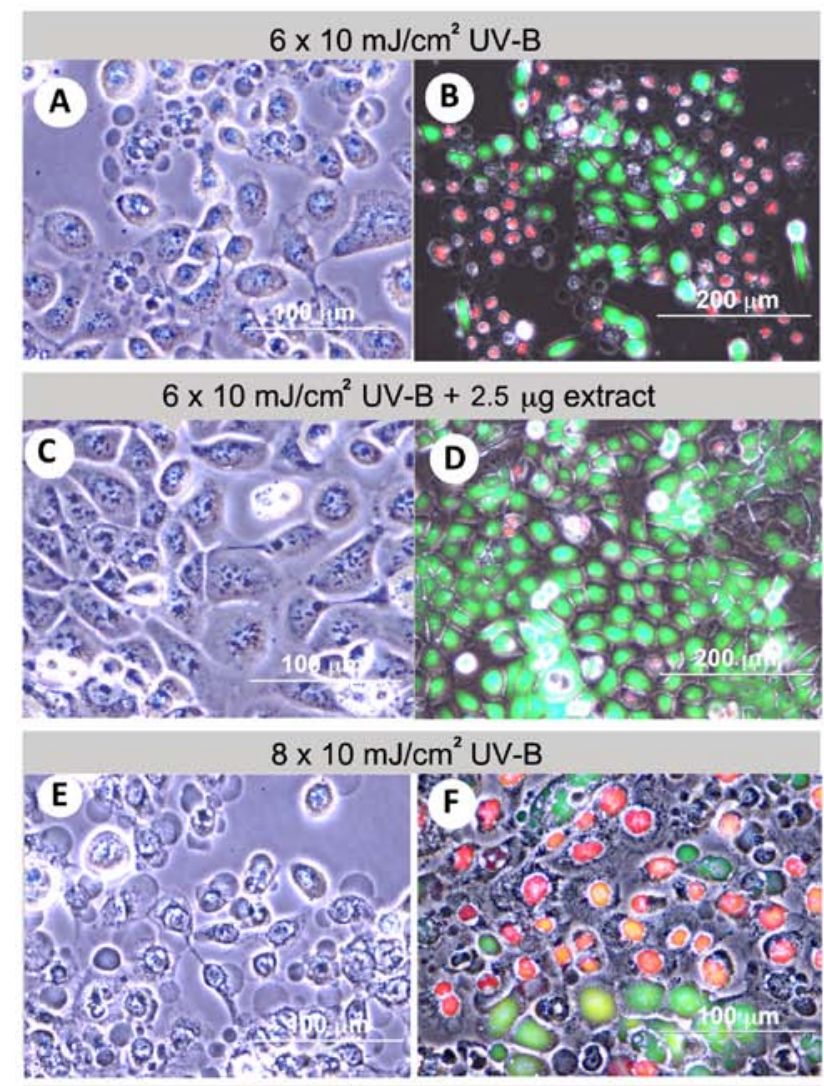

$8 \times 10 \mathrm{~mJ} / \mathrm{cm}^{2}$ UV-B $+2.5 \mu \mathrm{g}$ extract
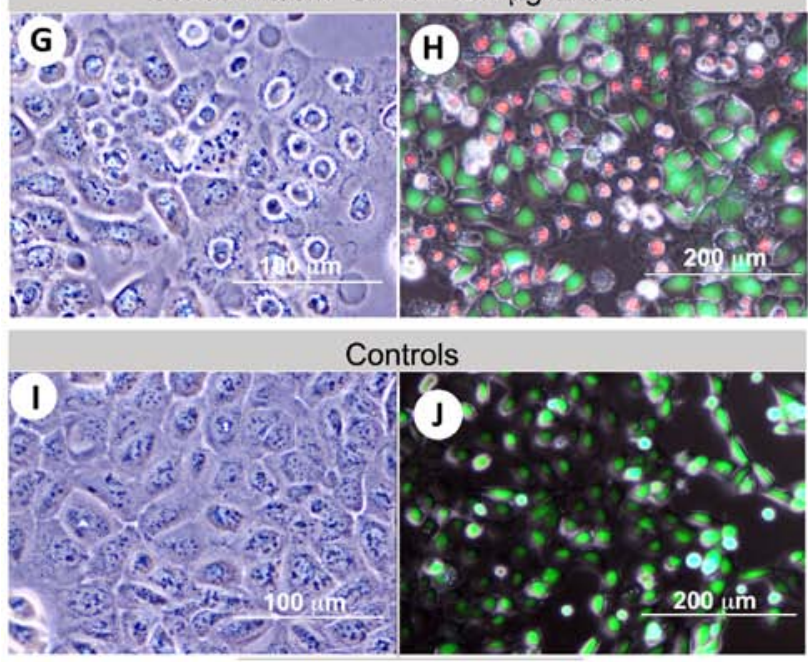

Figure 3. Protective effect of abalone extracts following UV-B exposure, based on cell survival and morphology. Bright field (left) and fluorescence (right) images showing $\mathrm{HaCaT}$ cells: (A and B) after exposure to $6 \times 10 \mathrm{~mJ} / \mathrm{cm}^{2}$ UV-B; (C and D) pre-treated with $2.5 \mu \mathrm{g} / \mathrm{ml}$ abalone extract and exposed to $6 \times 10 \mathrm{~mJ} / \mathrm{cm}^{2} \mathrm{UV}-\mathrm{B}$; (E and F) after exposure to $8 \times 10 \mathrm{~mJ} / \mathrm{cm}^{2} \mathrm{UV}-\mathrm{B}$ $(\mathrm{G}$ and $\mathrm{H})$ pre-treated with $2.5 \mu \mathrm{g}$ abalone extracts and exposed to $8 \times 10 \mathrm{~mJ} / \mathrm{cm}^{2}$ UV-B. (I and J) Controls with no UV-B exposure or to extract. Red staining represents dead cells and green staining represents live cells. Three morphological cell types are observed, shown as (A, E and G) membrane bubbling, (A and $\mathrm{E}$ ) condensation of cytoplasm and (A, E and $\mathrm{G}$ ) chromatin.

$>90 \%$ in the 2.5 and $5 \mu \mathrm{g} / \mathrm{ml}$ extract-treated groups at the same UV-B level (Fig. 2D and E). At 10x10 mJ/cm² UV-B, there was almost complete cell death $(0.84 \%$ survival $)$ in the control groups (Fig. 2F and G), while there was $>30 \%$ cell survival when cells were incubated with $2.5 \mu \mathrm{g} / \mathrm{ml}$ abalone extract at the same UV-B level (Fig. 2H and I).
Changes in cell morphology in response to $U V$-B and abalone extracts. To monitor changes in cell morphology by calcein AM-PI live-dead staining, phase contrast and fluorescence microscopy was used (Fig. 3A-J). HaCaT cell morphological changes and viability following UV-B exposure $\left(6 \times 10 \mathrm{~mJ} / \mathrm{cm}^{2}\right)$ were assessed in two groups: i) control group, where $\mathrm{HaCaT}$ cells were exposed to UV-B alone; and ii) the experimental group where $\mathrm{HaCaT}$ cells received $2.5 \mu \mathrm{g} / \mathrm{ml}$ abalone extracts (1:1 HBG and gill extract) before UV-B exposure. UV-B exposure resulted in three obvious changes in cell morphology: i) cytoplasmic condensation; ii) cell shrinkage and membrane budding; and iii) condensation of chromatin. Fig. 3A-D shows representative micrographs of $\mathrm{HaCaT}$ cells with morphological changes after exposure to $6 \times 10 \mathrm{~mJ} / \mathrm{cm}^{2} \mathrm{UV}-\mathrm{B}$ alone and with the abalone extract co-treatment. In the presence of $2.5 \mu \mathrm{g} / \mathrm{ml}$ of abalone extract, most cells were viable with only minor morphological changes being observed. At $8 \times 10 \mathrm{~mJ} / \mathrm{cm}^{2} \mathrm{UV}-\mathrm{B}$, most cells in the control group were dead (Fig. 3E and F) while in the experimental group there was $>50 \%$ cell survival (Fig. $3 \mathrm{G}$ and $\mathrm{H}$ ). This was also observed in the abalone extract-treated groups exposed to a higher UV-B dose $\left(10 \times 10 \mathrm{~mJ} / \mathrm{cm}^{2}\right)$. In the negative control (no UV-B exposure) (Fig. 3I and J), HaCaT cells appeared as round or rectangular in shape with an $\sim 40-80 \mu \mathrm{m}$ diameter. In addition, the nucleus occupied almost half of the total area (with 10-20 $\mu \mathrm{m}$ nucleolus), and the plasma membranes were clear, often attached to neighboring cells.

Measurement of inflammatory proteins following UV-B irradiation of $\mathrm{HaCaT}$ cells. Expression of inflammation-related proteins (COX-2, SPK/JNK, phospho-SPK/JNK, p38, and phospho-p38) was analyzed by western blot analysis of HaCaT cell extracts following UV-B exposure, with or without treatment with the abalone extracts (Fig. 4A and B). The control represents $\mathrm{HaCaT}$ cell extracts with no UV-B and no abalone extract. HaCaT cells were also exposed to UV-B $\left(3 \times 10\right.$ and $\left.5 \times 10 \mathrm{~mJ} / \mathrm{cm}^{2}\right)$ with or without $2.5 \mu \mathrm{g} / \mathrm{ml}$ abalone extract. No significant change was observed in $\beta$-actin protein levels for any treatment. Abalone extract did show more significant inhibition of COX-2 expression when compared to the levels observed at $3 \times 10$ and $5 \times 10 \mathrm{~mJ} / \mathrm{cm}^{2}$ UV-B. The extract also resulted in a more significant inhibition of the inflammatory-related active forms of SPK-JNK and p38, namely phospho-SPK-JNK and phospho-p-38, when compared to these levels following exposure to $5 \times 10 \mathrm{~mJ} / \mathrm{cm}^{2} \mathrm{UV}-\mathrm{B}$ without the extract.

\section{Discussion}

In the present study, we investigated the effects of extracts derived from abalone tissues well known for secreting mucus, to ascertain whether they attenuate UV-based cell damage. We found that abalone tissue extracts attenuated the effects of UV-B on HaCaT cells, as determined by both morphological and molecular analyses of inflammatory-related proteins.

Having established that HBG and gill extract doses less than $10 \mu \mathrm{g} / \mathrm{ml}$ were not detrimental to HaCaT cell survival, we then tested cell survival in the presence of various concentrations of extracts with UV-B exposure. We demonstrated the capacity for abalone extracts to inhibit the process of 


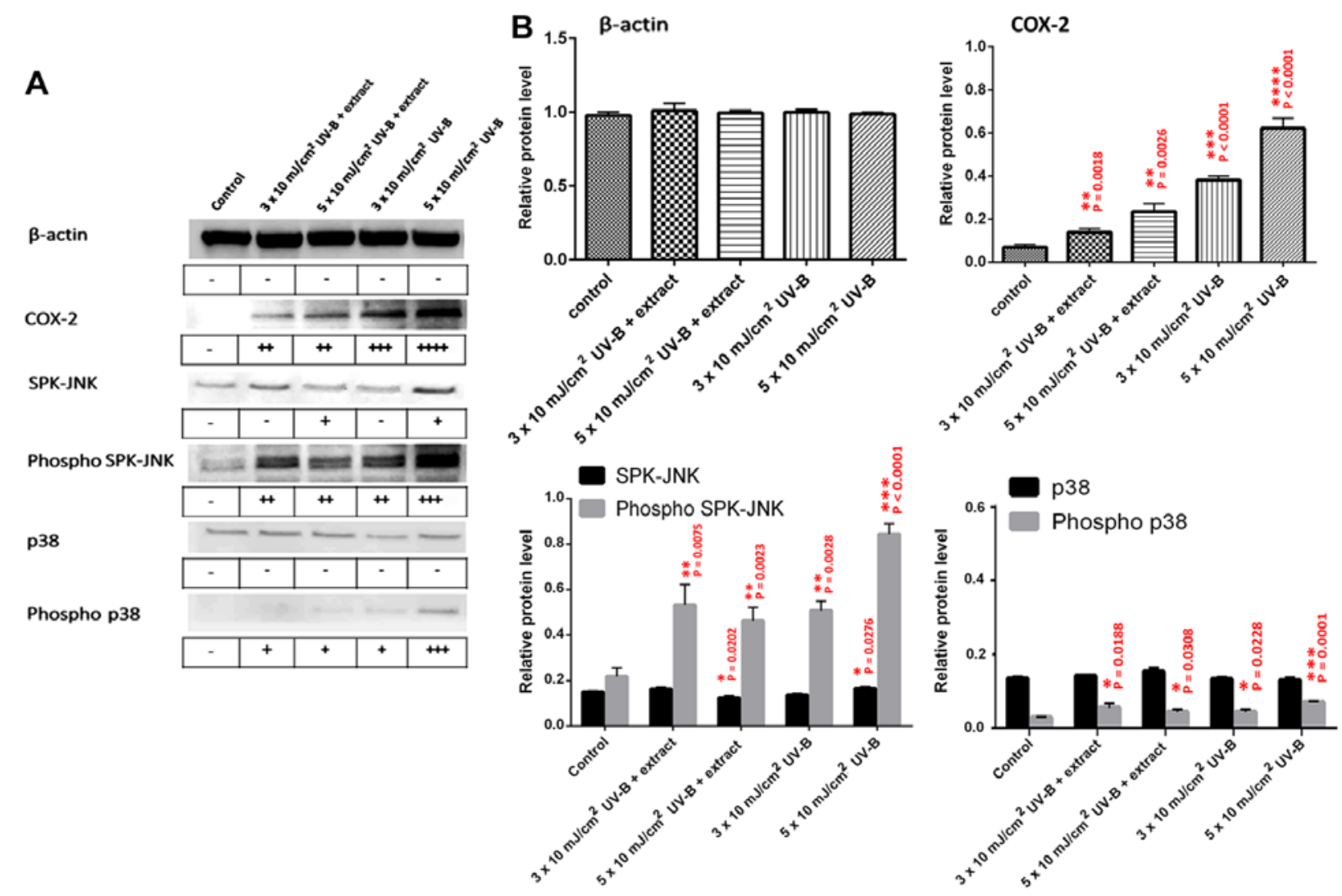

Figure 4. Western blot analysis of inflammatory-related proteins present in $\mathrm{HaCaT}$ cells after UV-B exposure and with abalone extract. (A) Representative western blots, and (B) graphs showing relative protein levels for each protein. Densities of bands (quantified using densitometry UN-SCAN-IT software) were compared to the control group to identify relative change. -, no significant difference; + , significant difference at $\mathrm{P}<0.05 ;++$, significant difference at $\mathrm{P}<0.01$; +++ , significant difference at $\mathrm{P}<0.001$; and ++++ , significant difference at $\mathrm{P}<0.0001$.

inflammation at 4-8 $\mathrm{mJ} / \mathrm{cm}^{2} \mathrm{UV}-\mathrm{B}$, and morphological analysis and protein expression profiling supported this. In the absence of extract (control) HaCaT cells showed cytoplasmic condensation, cell shrinkage, membrane budding and accumulation of the condensation of chromatin after being exposed to UV-B. In support of the protective effects of the abalone extracts, COX-2 and phosphorylated forms of SPK-JNK and p38, were relatively less highly expressed when the extracts were applied to HaCaT cells exposed to $5 \times 10 \mathrm{~mJ} / \mathrm{cm}^{2}$ UV-B

The UV absorbent properties of animal mucus have been well studied in fish and corals. In corals, the algal symbionts help determine the mucus composition, including the release of MAAs which protect against UV (42). Other biomolecules that may act against photochemical damage to UV-B include cytosolic water-soluble reductants and membrane-bound lipid-soluble antioxidants.

In tropical fish species, MAAs present within the epithelial mucus are critical for absorbing UV-A and UV-B, with strong absorbance peaks between 290 and $400 \mathrm{~nm}$ (19). The requirement for $\mathrm{UV}$-absorbent compounds in tropical water is essential, since this water is often low in UV-absorbing particulate and dissolved organic matter (43). H. asinina is distributed throughout many tropical regions worldwide, including the Great Barrier Reef (44). To date, analysis of its mucus composition has primarily focused on the existence of water-soluble peptides that may be required for non-specific communication, showing that there are three major water-soluble peptides that are released in large amounts from secretory cells and diffuse into the surrounding seawater (36). Future studies should explore the existence of MAAs, or other known and novel UV-absorbing biomolecules.

Besides the role of mucus in UV protection, other medically relevant applications should be explored. Of most interest are the bioactive compounds secreted by marine snails in the family Muricidae, and in particular their brominated indoles released from the HBG that appear to have anti-inflammatory, anticancer and steriodogenic activity (45). A recent study of the mosquito Aedes aegypti analyzed salivary gland extracts, demonstrating that semi-purified preparations can ameliorate inflammatory bowel disease (46). In addition, anti-inflammatory proteins have been discovered within the salivary gland extracts of the tick, Hyalomma anatolicumanatolicum (47) and horsefly Tabanusyao (48). Moreover, researchers discovered a free amino acid from Haliotis discus water named taurine, which has anti-inflammatory and antioxidant potentials in zebrafish (49). These types of discoveries clearly indicate that numerous other animal mucus-associated biomolecules could be used for human medicine. Moreover, numerous unpublished reports suggest the benefits of land snail mucus for skin anti-aging and wound healing. Abalone, also a gastropod, could possibly have similar, yet unexplored advantageous attributes.

In conclusion, the present study demonstrated the ability of biomolecules derived from tropical abalone gland extracts to attenuate UV-B damage. Without extract, HaCaT cell 
viability was significantly reduced upon exposure to UV-B at $5 \mathrm{~mJ} / \mathrm{cm}^{2}$. This was determined based on morphological changes, live-dead staining assay and analysis of changes in the abundance of inflammatory-related proteins. Subsequent research will be carried out to determine the exact factors in the abalone extracts that are responsible for these property.

\section{Acknowledgements}

We sincerely thank the Strategic Wisdom and Research Institute (Srinakharinwirot University, Thailand) and Research and Foreign Relation Department, Faculty of Medicine (Srinakharinwirot University, Thailand) for the financial support and professional cooperation.

\section{References}

1. de Gruijl FR and Van der Leun JC: Estimate of the wavelength dependency of ultraviolet carcinogenesis in humans and its relevance to the risk assessment of a stratospheric ozone depletion. Health Phys 67: 319-325, 1994.

2. Svobodova A, Walterova D and Vostalova J: Ultraviolet light induced alteration to the skin. Biomed Pap Med Fac Univ Palacky Olomouc Czech Repub 150: 25-38, 2006.

3. Nichols JA and Katiyar SK: Skin photoprotection by natural polyphenols: Anti-inflammatory, antioxidant and DNA repair mechanisms. Arch Dermatol Res 302: 71-83, 2010.

4. Afaq F: Natural agents: Cellular and molecular mechanisms of photoprotection. Arch Biochem Biophys 508: 144-151, 2011.

5. López-Camarillo C, Ocampo EA, Casamichana ML, PérezPlasencia C, Alvarez-Sánchez E and Marchat LA: Protein kinases and transcription factors activation in response to $\mathrm{UV}$-radiation of skin: Implications for carcinogenesis. Int $\mathrm{J} \mathrm{Mol}$ Sci 13: 142-172, 2012.

6. Bender K, Göttlicher M, Whiteside S, Rahmsdorf HJ and Herrlich P: Sequential DNA damage-independent and -dependent activation of NF-kappaB by UV. EMBO J 17: 5170-5181, 1998.

7. Hernandez-Pigeon H, Jean C, Charruyer A, Haure MJ, Titeux M, Tonasso L, Quillet-Mary A, Baudouin C, Charveron M and Laurent G: Human keratinocytes acquire cellular cytotoxicity under UV-B irradiation. Implication of granzyme B and perforin. J Biol Chem 281: 13525-13532, 2006.

8. Ali D, Verma A, Mujtaba F, Dwivedi A, Hans RK and Ray RS UV-B-induced apoptosis and DNA damaging potential of chrysene via reactive oxygen species in human keratinocytes. Toxicol Lett 204: 199-207, 2011.

9. Wu MS, Sun DS, Lin YC, Cheng CL, Hung SC, Chen PK, Yang JH and Chang HH: Nanodiamonds protect skin from ultraviolet B-induced damage in mice. J Nanobiotechnology 13: 35, 2015.

10. Devary Y, Rosette C, DiDonato JA and Karin M: NF-kappa B activation by ultraviolet light not dependent on a nuclear signal. Science 261: 1442-1445, 1993.

11. Buckman SY, Gresham A, Hale P, Hruza G, Anast J, Masferrer $\mathrm{J}$ and Pentland AP: COX-2 expression is induced by UV-B exposure in human skin: Implications for the development of skin cancer. Carcinogenesis 19: 723-729, 1998.

12. Muller-Decker K, Neufang G, Berger I, Neumann M, Marks F and Furstenberger G: Transgenic cyclooxygenase-2 overexpression sensitizes mouse skin for carcinogenesis. Proc Natl Acad Sci USA 99: 12483-12488, 2002.

13. Shibata A, Nakagawa K, Yamanoi H, Tsuduki T, Sookwong P, Higuchi O, Kimura F and Miyazawa T: Sulforaphane suppresses ultraviolet B-induced inflammation in $\mathrm{HaCaT}$ keratinocytes and HR-1 hairless mice. J Nutr Biochem 21: 702-709, 2010.

14. Liu S, Mizu H and Yamauchi H: Photoinflammatory responses to UV-irradiated ketoprofen mediated by the induction of ROS generation, enhancement of cyclooxygenase-2 expression, and regulation of multiple signaling pathways. Free Radic Biol Med 48: 772-780, 2010

15. Kim JE, Kwon JY, Seo SK, Son JE, Jung SK, Min SY, Hwang MK, Heo YS, Lee KW and Lee HJ: Cyanidin suppresses ultraviolet B-induced COX-2 expression in epidermal cells by targeting MKK4, MEK1, and Raf-1. Biochem Pharmacol 79: 1473-1482, 2010 .
16. Englaro W, Dérijard B, Ortonne JP and Ballotti R: Solar ultraviolet light activates extracellular signal-regulated kinases and the ternary complex factor in human normal keratinocytes. Oncogene 16: 661-664, 1998.

17. Ashida M, Bito T, Budiyanto A, Ichihashi M and Ueda M: Involvement of EGF receptor activation in the induction of cyclooxygenase-2 in HaCaT keratinocytes after UV-B. Exp Dermatol 12: 445-452, 2003.

18. El-Abaseri TB, Hammiller B, Repertinger SK and Hansen LA: The epidermal growth factor receptor increases cytokine production and cutaneous inflammation in response to ultraviolet irradiation. ISRN Dermatol 2013: 848705, 2013.

19. Zamzow JP and Losey GS: Ultraviolet radiation absorbance by coral reef fish mucus: Photo-protection and visual communication. Environ Biol Fishes 63: 41-47, 2002.

20. Jacobson PB and Jacobs RS: Fuscoside: An anti-inflammatory marine natural product which selectively inhibits 5-lipoxygenase. Part I: Physiological and biochemical studies in murine inflammatory models. J Pharmacol Exp Ther 262: 866-873, 1992.

21. Ojika M, Kigoshi H, Yoshida Y, Ishigaki T, Nisiwaki M, Tsukada I, Arakawa M, Ekimoto $\mathrm{H}$ and Yamada K: Aplyronine A, a potent antitumor macrolide of marine origin, and the congeners aplyronines B and C: Isolation, structures, and bioactivities. Tetrahedron 63: 3138-3167, 2007.

22. Uddin MH, Otsuka M, Muroi T, Ono A, Hanif N, Matsuda S, Higa T and Tanaka J: Deoxymanoalides from the nudibranch Chromodoris willani. Chem Pharm Bull (Tokyo) 57: 885-887, 2009.

23. Yamada K, Ojika M, Kigoshi H and Suenaga K: Aplyronine A, a potent antitumor macrolide of marine origin, and the congeners aplyronines B-H: Chemistry and biology. Nat Prod Rep 26: 27-43, 2009.

24. Adikwu MU and Alozie BU: Application of snail mucin dispersed in detarium gum gel in wound healing. Sci Res Essays 2: 195-198, 2007.

25. Santana WA, Melo CM, Cardoso JC, Pereira-Filho RN, Rabelo AS, Reis FP and Albuquerque-Júnior RLC: Assessment of antimicrobial activity and healing potential of mucous secretion of Achatina fulica. Int J Morphol 30: 365-373, 2012.

26. Shimidzu N, Goto M and Miki W: Carotenoids as singlet oxygen quenchers in marine organisms. Fish Sci 62: 134-137, 1996.

27. Bonnemain B: Helix and drugs: Snails for western health care from antiquity to the present. Evid Based Complement Alternat Med : eCAM 2: 25-28, 2005.

28. D'Orazio N, Gammone MA, Gemello E, De Girolamo M, Cusenza S and Riccioni G: Marine bioactives: Pharmacological properties and potential applications against inflammatory diseases. Mar Drugs 10: 812-833, 2012.

29. Cruz MC, Sanz-Rodríguez F, Zamarrón A, Reyes E, Carrasco E, González S and Juarranz A: A secretion of the mollusc Cryptomphalus aspersa promotes proliferation, migration and survival of keratinocytes and dermal fibroblasts in vitro. Int $\mathbf{J}$ Cosmet Sci 34: 183-189, 2012.

30. Chalermwat K, Szuster BW and Flaherty M: Shellfish aquaculture in Thailand. Aquac Econ Manag 7: 249-261, 2003.

31. Cook PA and Roy Gordon H: World abalone supply, markets, and pricing. J Shellfish Res 29: 569-571, 2010.

32. Wanichanon C, Laimek P, Linthong V, Sretarugsa P, Kruatrachue M, Upatham ES, Poomtong T and Sobhon P: Histology of hypobranchial glands and gills of Haliotis asinina Linnaeus. J Shellfish Res 23: 1107-1112, 2004.

33. Naegel LCA and Aguilar-Cruz CA: The hypobranchial gland from the purple snail Plicopurpura pansa (Gould, 1853) (Prosobranchia: Muricidae). J Shellfish Res 25: 391-394, 2006.

34. Laimek P, Clark S, Stewart M, Pfeffer F, Wanichanon C, Hanna P and Sobhon P: The presence of GABA in gastropod mucus and its role in inducing larval settlement. J Exp Mar Biol Ecol 354: 182-191, 2008.

35. Kuanpradit C, Cummins SF, Degnan BM, Sretarugsa P, Hanna PJ, Sobhon $\mathrm{P}$ and Chavadej J: Identification of an attractin-like pheromone in the mucus-secreting hypobranchial gland of the abalone Haliotis asinina linnaeus. J Shellfish Res 29: 699-704, 2010.

36. Kuanpradit C, Stewart MJ, York PS, Degnan BM, Sobhon P, Hanna PJ, Chavadej J and Cummins SF: Characterization of mucus-associated proteins from abalone (Haliotis) - candidates for chemical signaling. FEBS J 279: 437-450, 2012. 
37. Stewart P, Williams EA, Stewart MJ, Soonklang N, Degnan SM, Cummins SF, Hanna PJ and Sobhon P: Characterization of a GABAA receptor $\beta$ subunit in the abalone Haliotis asinina that is upregulated during larval development. J Exp Mar Biol Ecol 410: 53-60, 2011.

38. Seo MD, Kang TJ, Lee CH, Lee AY and Noh M: HaCaT keratinocytes and primary epidermal keratinocytes have different transcriptional profiles of cornified envelope-associated genes to T helper cell cytokines. Biomol Ther (Seoul) 20: 171-176, 2012.

39. Yang YL, Chang $\mathrm{CH}$, Huang $\mathrm{CC}$ and Liu HW: Anti- inflammation and anti-apoptosis effects of pearl extract gel on UV-B irradiation HaCaT cells. Biomed Mater Eng 26 (Suppl 1): S139-S145, 2015.

40. Kim SB, Kang OH, Joung DK, Mun SH, Seo YS, Cha MR, Ryu SY, Shin DW and Kwon DY: Anti-inflammatory effects of tectroside on UV-B-induced HaCaT cells. Int J Mol Med 31 1471-1476, 2013.

41. Al-Nasiry S, Geusens N, Hanssens M, Luyten C and Pijnenborg R: The use of Alamar Blue assay for quantitative analysis of viability, migration and invasion of choriocarcinoma cells. Hum Reprod 22: 1304-1309, 2007.

42. Shick JM, Lesser MP, Dunlap WC, Stochaj WR, Chalker BE and Won JW: Depth dependent responses to solar ultraviolet radiation and oxidative stress in the zooxanthellate coral Acropora microphthalma. Mar Biol 122: 41-51, 1995.

43. Baker KS, Smith RC and Green AES: Middle ultraviolet radiation reaching the ocean surface. Photochem Photobiol 32: 367-374, 1980.
44. Geiger DL: Distribution and biogeography of the recent Haliotidae (Gastropoda: Vetigastropoda) world-wide. Bollettino Malacologico 35: 57-120, 2000.

45. Benkendorff K, Rudd D, Nongmaithem BD, Liu L, Young F, Edwards V, Avila C and Abbott CA: Are the traditional medical uses of muricidae molluscs substantiated by their pharmacological properties and bioactive compounds? Mar Drugs 13: 5237-5275, 2015.

46. Sales-Campos H, de Souza PR, Basso PJ, Ramos AD, Nardini V, Chica JE, Capurro ML, Sá-Nunes A and de Barros Cardoso CR: Aedes aegypti salivary gland extract ameliorates experimental inflammatory bowel disease. Int Immunopharmacol 26: 13-22, 2015.

47. Ghosh M, Sangwan N and Sangwan AK: Partial characterization of a novel anti-inflammatory protein from salivary gland extract of Hyalomma anatolicum anatolicum (77Acari: Ixodidae) ticks. Vet World 8: 772-776, 2015.

48. Wei L, Huang C, Yang H, Li M, Yang J, Qiao X, Mu L, Xiong F, $\mathrm{Wu} \mathrm{J}$ and $\mathrm{Xu} \mathrm{W}$ : A potent anti-inflammatory peptide from the salivary glands of horsefly. Parasit Vectors 8: 556, 2015.

49. Cheong SH, Hwang JW, Lee SH, Kim YS, Sim EJ, You BI, Lee SH, Park DJ, Ahn CB, Kim EK, et al: In vitro and in vivo antioxidant and anti-inflammatory activities of abalone (Haliotis discus) water extract. Adv Exp Med Biol 803: 833-849, 2015. 